\title{
KODE ETIK JURNALISTIK DAN INDEPENDENSI PRODUKSI PROGRAM TELEVISI INVESTIGASI
}

\author{
Suwadi \\ wadi_suwadi@yahoo.com \\ Universitas Budi Luhur
}

\begin{abstract}
This study aims to determine and explain about the importance of the Kode Etik Jurnalistik (KEJ) used in producing television programs, including a program of investigation. The issue of the code of conduct associated with the ethical values underlying a production, and it is necessary so that a television program has the responsibility for the moral good. The object of this research is investigation television program of Sigi in Surya Citra televisi (SCTV) with regard to the Kode Etik Jurnalistik (KEJ) statutes of the Press Council (Dewan Pers), Article 2, Article 3, Article 4 and Article 5 of the current stage of reporting, script writing and editing. This study uses the theory of social responsibility equipped with a concept of the Independence by Mc Quail that opinion, accuracy, juxtaposition and Sensationalism. Research studies using qualitative methods of interviews and observation as a data collection tool. In-depth interviews conducted with informants of the production crew Sigi. Participatory observation was done to see the activity of production Sigi editor. This study found the program Sigi still there is a discrepancy with the code of Journalistic ethics on the stage of the coverage article 2, point $\mathrm{c}$ is not a bribe while another stage is in conformity with the provisions of articles 2,3,4 and 5 of the Kode Etik Jurnalistik (KEJ). The independence of the indicator of the opinion there is no element of opinion, accuracy indicator there are elements accurately in the reporting and writing of the manuscript, an indicator of Juxtaposition include an element of juxtaposition in writing of the manuscript, an indicator of sensationalism there is an element on the coverage and editing. To avoid the impact of short-term and long-term broadcasters (SCTV) should provide training on crew production news for the Kode Etik Jurnalistik (KEJ) because the value of ethics in a television production is very necessary and should be understood by the journalists involved in the production process. The application of the ethical values embodied in the code of conduct to be a manifestation of the independence of the media in the middle of attraction with a variety of interests that may occur in the production process of a television program such as investigation.
\end{abstract}

Key words: Journalistic Code of Ethics, Independence, Investigation.

\section{ABSTRAK}


Penelitian ini bertujuan untuk mengetahui dan menjelaskan mengenai pentingnya kode etik jurnalistik digunakan dalam memproduksi program televisi, termasuk program investigasi. Persoalan kode etik terkait dengan nilai-nilai etika yang mendasari sebuah produksi, dan hal itu sangat diperlukan sehingga sebuah program televisi mempunyai tanggung jawab moral yang baik. Obyek penelitian ini program investigasi Sigi di Surya Citra Televisi (SCTV) berkaitan dengan Kode Etik Jurnalistik (KEJ) ketetapan Dewan Pers Pasal 2, Pasal 3,Pasal 4 dan Pasal 5 saat tahap peliputan, penulisan naskah dan editing. Penelitian ini menggunakan teori Tanggung jawab sosial (social responsibility) dilengkapi dengan konsep-konsep Independensi Mc Quail, yaitu opini, akurasi, juxtaposition dan sensasionalisme. Kajian penelitian menggunakan pendekatan kualitatif dengan metode wawancara dan observasi sebagai alat pengumpul data. Wawancara mendalam dilakukan dengan informan para kru produksi Sigi. Observasi partisipasi dilakukan untuk melihat aktivitas produksi diredaksi Sigi. Kajian ini menemukan program Sigi masih ada ketidaksesuaian dengan kode etik Jurnalistik pada tahap peliputan pasal 2 point c, yaitu tidak menyuap sedangkan untuk tahap yang lain sudah sesuai dengan ketentuan pasal 2,3,4 dan 5 Kode Etik Jurnalistik. Independensi dari indikator opini tidak ada unsur opini, indikator akurasi ada unsur akurat dalam peliputan dan penulisan naskah, indikator Juxtaposition adanya unsur juxtaposition pada penulisan naskah, indikator sensasionalisme ada unsur pada peliputan dan editing. Untuk menghindari dampak jangka pendek dan jangka panjang dalam penyiaran sebaiknya lembaga penyiaran (SCTV) memberikan pelatihan dan training pada crew produksi berita mengenai Kode Etik Jurnalistik karena nilai etika dalam sebuah produksi televisi sangat diperlukan dan harus dipahami oleh para jurnalis yang terlibat dalam proses produksi. Penerapan nilai-nilai etika yang terwujud dalam kode etik menjadi wujud dari independensi media ditengah tarik menarik dengan berbagai kepentingan yang mungkin saja terjadi dalam proses produksi sebuah program televisi seperti investigasi.

\section{Kata Kunci: Kode Etik Jurnalistik, Independensi, Investigasi}

\section{PENDAHULUAN}

Kredibilitas lembaga penyiaran televisi dapat dilihat dari kualitas program beritanya. Hal ini pula yang kemudian mendorong stasiun televisi berlomba dan bersaing dalam mengemas sebuah peristiwa yang ingin diberitakan. Sebagaimana pendapat Adi Badjuri bahwa suatu berita memiliki nilai manakala berita tersebut dapat menggugah, menimbulkan rasa simpati, rasa marah dan lain sebagainya. (Badjuri, 2010:87)
Sementara tingginya nilai berita (news value) dipengaruhi oleh kemampuan para jurnalis dalam mendapatkan informasi maupun data-data yang berkaitan dengan peristiwa atau kejadian yang mereka liput. Untuk mendapatkan fakta dan kebenaran jurnalis terkadang harus melakukan investigasi/penyelidikan secara rahasia atau sembunyi-sembunyi. Investigation news adalah berita yang dikembangkan berdasarkan penulisan atau penyelidikan dari berbagai sumber. Berita jenis ini 
biasanya memusatkan pada sejumlah masalah dan kontroversi. Contoh program investigasi di media televisi di antaranya; Modus (Inews TV), Reportase Investigasi (TransTV), Sigi (SCTV), Metro Realitas (MetroTV), dan Telusur (TV One).

Menurut Robert Greene dari Newsday menyebutkan liputan investigasi merupakan karya seseorang atau beberapa wartawan atas suatu hal yang penting buat kepentingan masyarakat namun dirahasiakan (Fachruddin, 2012:253). Laporan investigatif seringkali direspon oleh penyelidik resmi pemerintah, yakni polisi, jaksa yang membawanya ke pengadilan. Jurnalisme investigasi mampu membuat publik sadar tentang masalah yang merugikan mereka. Namun bukan tidak mungkin apa yang disajikan kadang menimbulkan polemik, keresahan dan merugikan suatu kelompok tertentu dimasyarakat. Disinilah perlu disertakan nilai tanggung jawab pers yang seharusnya memberikan tayangan yang menyejukkan, berkontribusi menciptakan kedamaian dengan tidak saling membenturkan.

\section{KODE ETIK JURNALISTIK}

Dari beberapa kajian penelitian sebelumnya terindikasi program jurnalisme televisi investigasi sering melakukan komodifikasi, sehingga netralitas dan independensi peliputannya diragukan. Jika demikian etika dalam mencari dan mendapatkan berita belum dilaksanakan dengan semestinya. Etika yang dimaksud adalah etika di lingkungan pers. Menurut Zainnuddin, Kode Etik Jurnalistik merupakan landasan moral profesi dan ramburambu atau kaidah penuntun sekaligus pemberi arah kepada wartawan tentang apa yang seharusnya dilakukan dan apa yang seharusnya dihindari dalam melaksanakan tugas jurnalistik (Zaenuddin,2011:67).

Etika tidak hanya dibutuhkan dalam menjalani kehidupan bermasyarakat namun juga dalam menjalani suatu profesi tertentu yang kemudian disebut dengan etika profesi. Ini sesuai pendapat Wina Armada Sukardi, etika adalah kumpulan nilai moral bagi suatu profesi yang dibuat dari, oleh dan untuk profesi itu sendiri (Armada, 2008:4).

Kode Etik Jurnalistik (KEJ) yang dikeluarkan Dewan Pers melalui peraturan Dewan Pers no 6/PeraturanDP/V/2008 tentang Pengesahan Surat Keputusan Dewan Pers Nomor 03/SKDP/III/2006 tentang Kode Etik Jurnalistik Sebagai Peraturan Dewan Pers di Jakarta pada 14 Maret 2006. Kode etik ini berisi 11 pasal.

Fokus perhatian utama penelitian ini hanya pada Pasal 2, Pasal 3, pasal 4 dan Pasal 5. Berikut ini isi dan penafsiran pasal- pasal tersebut:

Pasal 2

Wartawan Indonesia menempuh
cara-cara profesional dalam
melaksanakan tugas jurnalistik
Penafsiran
Cara-cara yang profesional adalah:

Wartawan Indonesia menempuh cara-cara profesional dalam melaksanakan tugas jurnalistik

Penafsiran

Cara-cara yang profesional adalah: 
a. menunjukkan identitas diri kepada narasumber;

b. menghormati hak privasi

c. tidak menyuap

d. menghasilkan berita yang faktual dan jelas sumbernya;

e. rekayasa pengambilan dan pemuatan atau penyiaran gambar, foto, suara dilengkapi dengan keterangan tentang sumber dan ditampilkan secara berimbang;

f. menghormati pengalaman traumatik narasumber dalam penyajian gambar, foto, suara;

g. tidak melakukan plagiat, termasuk menyatakan hasil liputan wartawan lain sebagai karya sendiri;

h. penggunaan cara-cara tertentu dapat dipertimbangkan untuk peliputan berita investigasi bagi kepentingan publik.

Pasal 3

Wartawan Indonesia selalu menguji infomasi, memberitahukan secara berimbang, tidak mencampurkan fakta dan opini yang menghakimi, serta menerapkan azas praduga tak bersalah.

Penafsiran

a. Menguji informasi berarti melakukan check and recheck tentang kebenaran informasi itu.

b. Berimbang adalah memberikan ruang atau waktu pemberitaan kepada masing-masing pihak secara proporsional.

c. Opini yang menghakimi adalah pendapat pribadi wartawan. Hal ini berbeda dengan opini interpretatif, yaitu pendapat yang berupa interpretasi wartawan atas fakta.

d. Asas praduga tak bersalah adalah prinsip tidak menghakimi seseorang.

Pasal 4

Wartawan Indonesia tidak membuat berita bohong, fitnah, sadis dan cabul Penafsiran

a. Bohong berarti sesuatu yang sudah diketahui sebelumnya oleh wartawan sebagai hal yang tidak sesuai dengan fakta yang terjadi.

b. Fitnah berarti tuduhan tanpa dasar yang dilakukan secara sengaja dengan niat buruk.

c. Sadis berarti kejam dan tidak mengenal belas kasihan.

d. Cabul berarti penggambaran tingkah laku secara erotis dengan foto, gambar, suara, grafis atau tulisan yang semata-mata untuk membangkitkan nafsu birahi.

e. Dalam penyiaran gambar dan suara dari arsip, wartawan mencantumkan waktu pengambilan gambar dan suara.

Pasal 5

Wartawan Indonesia tidak menyebutkan dan menyiarkan identitas korban kejahatan susila dan tidak menyebutkan identitas anak yang menjadi pelaku kejahatan.

Penafsiran

a. Identitas adalah semua data dan informasi yang menyangkut diri seseorang yang memudahkan orang lain untuk melacak.

b. Anak adalah seorang yang berusia kurang dari 16 tahun dan belum menikah.

\section{INDEPENDENSI}

Dalam jurnalisme terkandung idealisme, ada suatu ideologi, yaitu usaha memberikan informasi untuk pemberdayaan masyarakat (Siregar, Kompas, 21 Juli 2013). Menurut Siregar, dalam jurnalisme dan kegiatan 
jurnalistik, terdapat prinsip independensi dan netralitas yang harus ditegakkan. Independen dalam arti merdeka melaksanakan ideologi jurnalisme, sedangkan netral artinya berimbang, akurat, tak memihak kecuali demi kepentingan publik. Independensi media berarti bahwa dalam memproduksi isi media tidak ada tekanan dari pihak lain. Independensi didefinisikan sebagai kemerdekaan yang dimiliki oleh ruang redaksi dalam memproduksi berita. Selanjutnya, bila independensi lebih berkaitan dengan proses produksi berita, maka netralitas lebih berkaitan dengan apa yang muncul di dalam berita. Netralitas menunjukkan bahwa media tidak berpihak dalam menyampaikan berita.

McQuail (1992) menguraikan beberapa indikator penting dalam melihat persoalan independensi (objektivitas) dan netralitas, di antaranya: ada tidaknya opini, unsur personalisasi, sensasionalisme, stereotype, juxtaposition atau linkage, dan akurasi dalam pemberitaan.

Berdasar latar teoritis tersebut kajian ini akan mengetahui proses produksi tayangan investigasi di salah satu televisi swasta nasional SCTV, yakni Program Sigi. Penulis menggunakan kode etik jurnalistik sebagai kajian analisanya. Sehingga penulis merumuskan permasalahan penulisan sebagai berikut:

1 Bagaimana bentuk penerapan etika jurnalistik dalam produksi program investigasi Sigi SCTV berkaitan dengan Kode Etik Jurnalistik (KEJ) ketetapan
Dewan Pers Pasal 2, Pasal 3, Pasal 4 dan Pasal 5 saat peliputan, penulisan dan editing.

2 Bagaimana independensi dalam produksi program investigasi SIGI SCTV meliputi saat peliputan berita, penulisan naskah, dan editing.

Sehingga tujuan kajian ini adalah memeroleh gambaran penerapan etika sebagai bentuk independensi dalam produksi program jurnalisme televisi investigasi Sigi SCTV yang pada harapannya penelitian ini akan memberi wawasan kesadaran kepada masyarakat.

\section{METODE PENELITIAN}

Penelitian ini bertujuan untuk memberikan gambaran dan mengungkap fakta-fakta secara detail dengan interpretasi yang dikumpulkan. Menurut Jalaludin Rahmat metode deskriptif adalah sebuah metode yang hanya memaparkan situasi atau peristiwa. Penelitian ini tidak mencari atau menjelaskan hubungan, tidak menguji hipotesis atau membuat prediksi. Sedangkan metode pengumpulan data, yakni data primer berdasarkan wawancara mendalam, dan observasi sedangkan data sekunder dengan menganalisis isi tayangan program, studi literatur dan artikel di internet yang mendukung penulisan ini. Metode wawancara mendalam merupakan metode riset di mana periset melakukan wawancara tatap muka secara mendalam dan terus menerus (lebih dari satu kali) untuk menggali responden (Kriyantono, 2006:65). Wawancara tersebut dilakukan terhadap informan kerabat 
kerja tim Sigi meliputi 2 orang Video Jurnalis atau Reporter, 1 orang Penulis naskah dan 2 orang Video Editor. Penulis juga menggunakan informan netral dari Dewan Pers sebagai pihak berkompeten dalam penerapan kode etik jurnalistik di lingkungan pers. Penelusuran literatur dilakukan untuk menemukan dan menguatkan data dan konsep yang diperlukan dalam kajian ini.

\section{HASIL DAN PEMBAHASAN}

Sigi merupakan program acara televisi yang disiarkan di Surya Citra Televisi (SCTV) setiap hari Minggu jam 01.00 WIB dinihari. Sigi diproduksi oleh Redaksi Liputan 6, Departemen Current Affairs (Progsus) berdurasi tayang 30 menit. Program ini berbentuk reportase investigasi tentang berbagai masalah sosial-kemasyarakatan, politik, hukum, ekonomi, budaya yang sedang hangat dibicarakan pada pekan-pekan terakhir dan memiliki sisi-sisi gelap yang belum terungkap di media massa.

\section{Etika Dalam Produksi Jurnalisme Televisi Investigasi Sigi}

Penerapan Pasal 2 di tahap Peliputan ditemukan sebanyak lima (5) kesesuaian. Kesesuaian tersebut pada penafsiran point a. poin b. poin d. poin $g$ dan poin $h$. Namun ditemukan juga Pelanggaran pada penafsiran butir c, tidak menyuap.Sedangkan pada Penulisan naskah dan editing penulis tidak menemukan data adanya pelanggaran maupun kesesuaian pada pasal 2 tersebut. Kode Etik Jurnalitik Pasal 2: Wartawan Indonesia menempuh caracara profesional dalam melaksanakan tugas jurnalistik. Berikut tabel hasil penulisannya (lihat tabel 1).

\section{Tabel 1}

Penerapan KEJ Pasal 2 pada Peliputan, Penulisan dan Editing Sigi

\begin{tabular}{|c|c|c|c|}
\hline \multirow[t]{2}{*}{ NO. } & \multirow{2}{*}{$\begin{array}{l}\text { POINT/BUTIR } \\
\text { PENAFSIRAN }\end{array}$} & \multicolumn{2}{|c|}{ HASIL PENELITIAN } \\
\hline & & TIDAK SESUAI & SESUAI \\
\hline 1. & a. Menunjukkan identitas diri kepada narasumber & & $\mathbf{V}$ \\
\hline 2. & b. Menghormati hak privasi & & $\mathbf{V}$ \\
\hline 3. & c. Tidak menyuap & $\mathbf{V}$ & \\
\hline 4. & d. Menghasilkan berita yang faktual dan jelas sumbernya & & $\mathbf{V}$ \\
\hline 5. & $\begin{array}{l}\text { e. Rekayasa pengambilan dan pemuatan atau penyiaran } \\
\text { gambar, foto, suara dilengkapi dengan keterangan tentang } \\
\text { sumber dan ditampilkan berimbang }\end{array}$ & & \\
\hline 6. & $\begin{array}{l}\text { f. Menghormati pengalaman traumatik narasumber dalam } \\
\text { penyajian gambar, foto, suara }\end{array}$ & & \\
\hline 7. & $\begin{array}{l}\text { g. Tidak melakukan plagiat termasuk menyatakan hasil } \\
\text { liputan wartawan lain sebagai karya sendiri }\end{array}$ & & $\mathbf{V}$ \\
\hline 8. & $\begin{array}{l}\text { h. Penggunaan cara-cara tertentu dapat dipertimbangkan } \\
\text { untuk peliputan berita invstigasi bagi kepentingan publik }\end{array}$ & & $\mathbf{V}$ \\
\hline
\end{tabular}

Keterangan : V peliputan; X penulisan ; Y editing

Dalam peliputan para jurnalis atau wartawan dibekali oleh lembaga atau perusahaan media berupa kartu identitas (name tag), kartu pers maupun baju seragam (uniform) untuk menunjukkan identitas agar mempermudah identifikasi. Namun dalam peliputan Sigi, identitas tersebut disembunyikan 
dengan pertimbangan banyak faktor. Berkaitan menunjukkan identitas tersebut key informan Dwi Sapto, Reporter Sigi menjelaskan :

"Pada awalnya mungkin tidak, jadi jujur seperti itu kita juga enggak bisa masuk. Langsung terbuka seperti itu tidak bisa. Begitu kita sudah blending, sudah berkawan ya pelan-pelan kita utarakan, biasanya berhasil. Karena dia pasti juga mau karena berteman, yang penting rahasia identitas segala macem aman, mereka biasanya mau" (Wawancara dengan Dwi Sapto, Reporter Sigi, 03 Juni 2016)

Tidak ditunjukannya identitas wartawan key informan Ratna Komala, Dewan Pers mengatakan :

"Sebetulnya dalam beberapa workshop atau pelatihan wartawan itu diberikan bekal untuk melindungi dari segala macam bahaya ketika dia bekerja juga, nah salah satu untuk wartawan investigasi menyembunyikan identitasnya, tetapi yang penting hasil kerja jurnalistik itu adalah hasil proses verifikasi yang berulang yang akurat" (Wawancara dengan Ratna Komala, Anggota Dewan Pers pada 23 Agustus 2016)

Saat melakukan peliputan Sigi, wartawan investigasi tidak sertamerta menunjukkan identitas sebagai wartawan saat peliputan, wartawan menjaga kerahasiaannya untuk mendapatkan informasi yang sengaja ditutupi padahal sangat penting bagi kemaslahatan publik. Hanya dengan cara demikian wartawan investigasi bisa leluasa meliput dan dengan cara ini bisa memeroleh momen-momen yang akan sangat sulit didapatkan jika ia terbuka identitasnya dalam peliputan.

Menurut Ratna Komala, anggota Dewan Pers masa bakti 2016-2021 Investigasi yang mengumpulkan data dari serpihanserpihan artinya tidak langsung dari pusat informasinya cenderung dari sisi tepi pinggiran dulu atau istilahnya merangkai puzzle, wartawan harus punya kebebasan untuk menggali dalam rangka mengumpulkan informasi itu secara baik dan independen kalau misalnya ada identitas akan ada reaksi menolak bahkan mengancam keselamatannya.

Jika dikaitkan antara data observasi dan informasi dari key informan, sekilas terjadi ketidaksesuaian dalam penerapan Pasal 2 point a, yaitu tidak ditunjukkannya identitas karena alasan tertentu. Namun hasil observasi penulis mendapatkan pada akhir liputannya reporter Sigi akan jujur dan terbuka pada narasumber bahwa ia wartawan media televisi. Sehingga penerapan KEJ ada kesesuaian pada pasal 2 penafsiran butir a.

Tidak mudahnya untuk mendapatkan materi liputan investigasi, hingga alasan simbiosis mutualisme atau kerjasama saling menguntungkan antara reporter dan narasumber menjadikan ikatan nilai materi sebagai hal yang dianggap wajar, karena jika tidak menggunakan materi pendekatan ke pelaku kejahatan akan sulit. Menjelaskan penafsiran tidak menyuap tersebut. key informan Ari Trisna, Video jurnalis Sigi berpendapat:

"Ada saya berpikiran informasi itu mahal mas, informasi itu mahal saya 
juga untuk e memberi imbalan ke sesorang itu ya saya ada flashback sebaliknya situ memberi saya apa informasi sebanyak apa yang saya perlukan ya itulah yang saya kasih" (Wawancara dengan Ari Trisna, video jurnalis Sigi pada 20 Juni 2016)

Berkaitan dengan hal pemberian imbalan Ratna Komala berpendapat :

"Kalau ucapan terima kasih menurut saya nggak papa ya karena konteksnya si wartawan itu mengucapkan terimakasih sesudah wawancara. Tapi juga akan berbeda kalau ia memberikan sesuatu sebelum wawancara terus wawancara sendiri terganggu ininya apa namanya jawaban-jawaban narasumber sendiri siapapun itu jadi terpengaruh karena dikasih iming-iming apapun deh namanya bingkisan atau apa. Jadi sebetulnya memang lebih baik tidak ada dalam pekerjaan jurnalistik tidak ada apapun deh namanya pemberian imbalan apapun." (Wawancara dengan Ratna Komala, Anggota Dewan Pers pada 23 Agustus 2016)

Pelanggaran atau ketidaksesuaian yang ditemukan pada Pasal 2 penafsiran poin c tidak menyuap, sangat mengganggu dan bertentangan apalagi jika wartawan tersebut telah membaca dan memahami KEJ. Pemberian suap atau imbalan akan memengaruhi subyektifitas narasumber karena besar atau kecil dari imbalan tentu berimbas pada besar kecilnya informasi. Berdasarkan wawancara tim Sigi tidak jarang imbalan ini dibicarakan diawal sebelum kesepakatan pemberian informasi. Pendekatan konvensional dengan ukuran materi ini mengarahkan pada sikap tidak professional dan fair. Akan lebih bijaksana jika pendekatan lain digunakan misalnya pendekatan pertemanan meski cara ini akan lama dan menyita waktu namun hasil yang diperoleh akan lebih obyektif.

Soal suap ini Ratna Komala berpendapat kalau terjadi pemberian apapun bentuknya (uang atau barang) dikhawatirkan memengaruhi laporan jurnalistiknya. Kalau ucapan terimakasih menurut anggota Dewan Pers tidak apaapa karena konteksnya si wartawan itu mengucapkan terima kasih sesudah wawancara. Tapi juga akan berbeda kalau wartawan memberikan sesuatu sebelum wawancara dan wawancaranya sendiri terganggu. Menurut penulis fenomena pemberian imbalan seperti jual-beli barang, semakin mahal semakin bagus dan berkualitas artinya data informasi yang diberikan sumber berita disesuaikan dengan jumlah materi yang ia terima. Dalam iklim jurnalisme seperti itu sehebat apapun seorang wartawan, dia tidak bisa berbuat banyak bila media tempatnya bekerja tidak memiliki modal membeli berita. Akibatnya, eksklusivitas sebuah berita sangat ditentukan oleh uang, bukan ketrampilan para wartawannya

Berkaitan dengan Kode Etik Jurnalistik pasal 2 penafsiran poin c dengan hasil data wawancara dan observasi, terjadi ketidaksesuaian penerapan atau pelanggaran. Apalagi pemberian imbalan ada yang dilakukan diawal sebelum peliputan tersebut.

Keterbatasan tim investigasi Sigi adalah kurangnya sumber daya manusia sehingga untuk memperkuat informasi 
tim Sigi sering mengambil data dari sumber lain yang bukan dari hasil liputan reporternya. Pada penafsiran butir g. tidak melakukan plagiat, termasuk menyatakan hasil liputan wartawan lain sebagai karya sendiri; Berkaitan dengan hal plagiat tersebut key informan Dwi Sapto menjelaskan,

"Saya bukan tipikal orang yang sebenarnya bukan memungut berita, tapi bukan juga menciptakan berita tapi saya coba mengungkap peristiwa yang tidak diketahui orang lain dan itu menjadi berita, tapi tidak menutup kemungkinan juga informasi dari wartawan lain. Misal itu penting kenapa tidak? Tapi balik lagi soal kebijakan redaksi Liputan 6 redaksi Sigi sendiri, pengalaman kalau ngambil dari tv lain nggak ya. Jadi kita biasa mengambil dari teman-teman NGO . Kita tulis courtesy karena itu bukan hak cipta di kita tapi di mereka. Salah kalau tidak kita tulis courtesy." (Wawancara dengan Dwi Sapto, Reporter Sigi, 03 Juni 2016)

Pendapat yang hampir sama disampaikan anggota Dewan Pers, Ratna Komala:

"Sumber data itu kan bisa diperoleh dari mana saja asalkan tidak mencuri. Plagiat itu mengambil tanpa ijin, memuat tanpa ijin, menggunakan tanpa ijin atau meniru misalnya ini sebenarnya tulisan si A tapi dia tiru diakui sebagai tulisannya dia. Salah satunya adalah kalau kita menggunakan sumber referensi, sumber data itu boleh dari mana saja asalkan dengan ijin. Kalau sudah mendapatkan ijin nggak masalahkan? disebutkan courtesy anu atau nggak kalau pakai foto by siapa kalau video courtesy siapa gitu kan, nah itu yang namanya etika. Apa yang terjadi jika tidak dicantumkan? Itu bisa berujung somasi karena menggunakan properti hak cipta orang lain copyright. Itu bisa diperkarakan." (Wawancara dengan Ratna Komala, Anggota Dewan Pers pada 23 Agustus 2016)

Mengenai penggunaan informasi dari mana saja menurut penulis adalah hal yang dibenarkan asalkan telah memeroleh izin dan mencantumkan courtesy. Hal ini adalah upaya media massa menghormati hak cipta orang lain seperti mengambil tayangan dari Youtube, dari NGO, atau LSM. Tidak dicantumkannya sumber atau courtesy atas pengambilan gambar orang lain akan menimbulkan somasi atau keberatan dari pihak yang dirugikan. Tindakan tidak terpuji tersebut yang disebut dengan plagiat, yakni menyatakan hasil liputan wartawan lain sebagai karya sendiri. Namun hal plagiat tidak ditemukan dalam produksi Sigi. Artinya dalam tayangan Sigi ada kesesuaian penerapan pasal, yakni dicantumkannya teks Courtesy pada visual atau gambar yang diambil dari pihak lain.

Peliputan Sigi lebih banyak dilakukan menggunakan kamera terbuka, kemudian diikuti teknik pengambilan gambar secara candid camera. Pada tayangan Sigi di hari Minggu, 4 Juni 2016. Episode Awas Predator Anak. Penulis mendapatkan beberapa visual pengambilan gambar dengan kamera tersembunyi. Anggota Dewan Pers, Ratna Komala berpendapat mengenai penggunaan hidden kamera. 
"Bagian dari menyembunyikan identitas alat bantunya hidden kamera. Kalau terus terang pakai kamera kan pasti tidak akan tercapai fakta yang sebenarnya. Fakta sebenarnya tidak akan diperoleh. Bahkan tadi sebaliknya ia akan terancam jika memperlihatkan kamera walaupun wartawan itu bekerja dilindungi Undang-Undang... Hidden kamera digunakan untuk memeroleh momen yang mungkin tidak terjadi kalau diambil nggak pakai hidden kamera." (Wawancara dengan Ratna Komala, Anggota Dewan Pers pada 23 Agustus 2016)

Berkaitan dengan Pasal 2 Penafsiran butir h. dari hasil observasi dan wawancara terdapat kesesuaian penerapan. Reporter Sigi menggunakan hidden camera namun tetap mentaati etika dalam penyiarannya. Hal itu dilakukan jika peliputan demikian penting untuk diketahui publik.

Pada penerapan Pasal 3 di tahap Peliputan ditemukan sebanyak 2 (dua) kesesuaian. Kesesuaian Pasal 3 tersebut pada penafsiran point a., dan point $b$. Penerapan Pasal 3 di tahap Penulisan naskah ditemukan sebanyak 2 (dua) kesesuaian. Kesesuaian Pasal 3 tersebut pada penafsiran poit a dan point $d$. Sedangkan di tahap Editing tidak ada data yang ditemukan.

Kode Etik Jurnalistik Pasal 3:

Wartawan Indonesia selalu menguji informasi, memberitahukan secara berimbang, tidak mencampurkan fakta dan opini yang menghakimi, serta menerapkan azas praduga tak bersalah. Berikut data tabelnya (lihat tabel 2).

Tabel 2

Penerapan KEJ Pasal 3 pada Peliputan, Penulisan, Editing Sigi

\begin{tabular}{|l|l|c|c|}
\hline NO. & \multicolumn{1}{|c|}{\begin{tabular}{c}
\multicolumn{1}{|c|}{ POINT/BUTIR } \\
PENAFSIRAN
\end{tabular}} & \multicolumn{1}{c|}{ HASIL PENELITIAN } \\
\hline 1. & $\begin{array}{l}\text { a. Menguji informasi berarti melakukan check dan } \\
\text { ricek tentang kebenaran informasi }\end{array}$ & & X \\
\hline 2. & $\begin{array}{l}\text { b. Berimbang adalah memberikan ruang dan waktu } \\
\text { pemberitaan kepada masing-masing pihak secara } \\
\text { proposional }\end{array}$ & & V \\
\hline 3. & $\begin{array}{l}\text { c. Opini yang menghakimi adalah pendapat pribadi } \\
\text { wartawan. Hal ini berbeda dengan opini } \\
\text { interpretative,yaitu pendapat yang berupa interpretasi } \\
\text { wartawan atas fakta. }\end{array}$ & & \\
\hline 4. & $\begin{array}{l}\text { d. azas praduga tak bersalah adalah prinsip tidak } \\
\text { menghakimi seseorang }\end{array}$ & & $\mathbf{X}$ \\
\hline
\end{tabular}

Keterangan: V peliputan; X penulisan ; Y editing

Pada tayangan Sigi Hari Minggu, 27 Maret 2016 Episode Kisruh Regulasi Angkutan Umum, penulis menemukan adanya dua pihak yang berkonflik, yakni pihak Taxi Konvensional dan Taxi online. Tim Sigi meng-cover dua pihak dengan cukup berimbang, ini diwakili oleh manajemen kedua perusahaan taksi tersebut. Sedangkan Pada Tayangan Sigi
Minggu, 22 Mei 2016 Episode Prahara Teluk Jakarta, penulis juga menemukan keberimbangan dalam peliputan dari pihak yang pro dengan penyedotan pasir pantai di Banten serta pihak yang menentang keberadaan pengambilan pasir pantai oleh Kapal Queen of the Nedherland. 
Dan mengenai keberimbangan ini key informan Dwi Sapto, Reporter Sigi mengatakan,

"Enggak ya jadi secara professional kita berpikir balik lagi soal kesimbangan bukan berarti durasi mesti sama ya tapi di situ mereka punya hak jawab yang sama... " (Wawancara dengan Dwi Sapto, reporter Sigi , 03 Juni 2016)

Menjelaskan keberimbangan Ratna Komala menjelaskan,

"...mengenai tuduhan pihak lain tentu saja kita tidak boleh menerima mentahmentah dong, pasti harus coverboth side tapi bukan hanya cover both side tapi multi side bukan cuma dua pihak kalau dua pihak ini belum cukup boleh melakukan konfirmasi pihak lain yang mungkin bisa memberikan gambaran lain." (Wawancara dengan Ratna Komala, Anggota Dewan Pers pada 23 Agustus 2016)

Jika dianalisa dengan teori Tanggungjawab Sosial mengenai keberimbangan pada Pasal 3 penafsiran poin $b$, jika pers hanya memberitakan salah satu pihak, maka hanya memberikan satu sisi kebenaran. Dengan memberikan kesempatan para pihak yang terlibat dikutip keterangannya atau diberi kesempatan mengutarakan pikirannya/versinya, pers telah berfungsi sebagai wadah dialog dan arena bertukar informasi. Namun terkadang masih sering ditemukan wartawan membuat berita berdasarkan keterangan dari sumber tunggal tanpa pengecekan atau konfirmasi dari sumber lain cara seperti ini menyebabkan berita menjadi timpang atau berat sebelah. Inilah yang disebut berita sepihak. Kendati layak sebagai berita, berita sepihak dianggap kurang sempurna. Namun menurut penulis hal demikian tidak ditemukan di produksi program Sigi, ini yang menjadikan Sigi memiliki fungsi bukan hanya sekedar informasi tapi memiliki fungsi referensi karena keberimbangan yang dilakukan para reporternya.

Berita berimbang merupakan berita yang sempurna yang layak dipublikasikan karena syarat cover both side terpenuhi. Berita berimbang memperkecil resiko yang dapat ditimbulkan seperti terjadinya komplain atau gugatan narasumber berita lainnya. Berita berimbang bukan hanya memberikan keadilan bagi para sumber berita melainkan juga sangat penting bagi audiens. Menurut MC Quail salah satu prinsip-prinsip dasar dari teori tanggungjawab sosial, media secara keseluruhan harus menjadi pluralis dan mencerminkan keragaman masyarakat, memberikan akses kepada berbagai sudut pandang dan hak-hak untuk menjawab. (Baran, 2010:146)

Sigi menggunakan data yang kuat, dilengkapi dengan gambar-gambar atau pernyataan dari narasumber, pelaku atau aparat berwenang untuk mendukung fakta yang sebenarnya. Pada Tayangan Sigi Minggu, 03 April 2016 di Episode Bencana Tanah Longsor di Batulawang, secara proposional tayangan Sigi menyajikan narasumber yang berkompeten mulai dari BKSDA, Aparatur Kelurahan, pemerhati lingkungan hingga mitigasi bencana 
dengan dukungan data yang cukup kuat. Berkaitan menguji informasi, key informan Dwi Sapto, Reporter Sigi menjelaskan:

" balik lagi pokoknya intinya gini deh.. data yang kita dapat jangan main-main jika data itu tidak kuat, jangan pernah mengasumsi, menduga." (Wawancara dengan Dwi Sapto,Reporter Sigi, 03 Juni 2016)

Berkaitan dengan Pasal 3 penafsiran poin $\mathrm{a}$ dan $\mathrm{b}$ terdapat kesesuaian penerapan. Reporter Sigi menggunakan berbagai sumber data yang jelas dan berimbang untuk mendukung topik bahasan. Informasi yang didapatkan seorang wartawan tidak hanya terbatas dari interview narasumber tapi juga datang dari sumber lain. Hal tersebut tentu saja harus dilakukan uji informasi atau cross chek dengan pihak yang berkompeten. Berkaitan menguji informasi, key informan Bagus Adi Nugroho, penulis naskah Sigi menjelaskan:

“... kalau saya kan sekaligus Reporter dan penulis naskah. Ya memang saya harus konfirmasi langsung. Jadi saya dengar cerita langsung dari narasumber yang mau diambil gambarnya... Dari situ saya harus tahu persis.. Jadi bukan karena cerita dari orang lain ya. Ya narasumber ya saya yang tanya. (Wawancara dengan Bagus Adi Nugroho, Penulis naskah dan Reporter Sigi, 25 Mei 2016)

Menurut Ratna Komala dari Dewan Pers,

"mendapat informasi dari kabar burung nggak boleh wartawan itu langsung menayangkan tanpa melakukan verifikasi. Kepada siapa ya pada sumbersumber yang kompeten yang bisa dipercaya." (Wawancara dengan Ratna Komala, Anggota Dewan Pers pada 23 Agustus 2016)

Menguji informasi berawal dari sikap skeptis dari seorang jurnalis. Ia tidak menelan bulat-bulat informasi yang diberikan narasumber namun perlu diuji terlebih dahulu dengan melakukan konfirmasi dengan instansi atau pihak terkait. Menurut anggota Dewan Pers, Ratna Komala uji informasi adalah verifikasi. Wartawan setelah mendapatkan kabar burung tidak boleh langsung menayangkan tanpa melakukan verifikasi kepada sumber kompeten dan dapat dipercaya. Dalam Sigi hal verifikasi ini telah dilakukan dan menjadi hal yang wajib. Berkaitan tanggungjawab sosial media wajib menetapkan standar profesi yang tinggi, berupa pemenuhan informasi, kebenaran, ketepatan, objektivitas dan keseimbangan.

Berkaitan dengan Pasal 3 penafsiran poin a. terdapat kesesuaian penerapan. Penulisan naskah Sigi melakukan uji informasi sebelumnya dengan narasumber karena penulis naskah yang melakukan wawancara langsung di lapangan.

Dalam Sigi Episode Lika-liku Bisnis Haram Aborsi tayang di Hari Minggu, 6 Maret 2016, penulis mendapatkan naskah narasi Sigi, berikut petikannya: 


\begin{tabular}{|l|l|c|c|}
\hline 1. & $\begin{array}{l}\text { a. Bohong berarti sesuatu yang sudah diketahui } \\
\text { sebelumnya oleh wartawan sebagai hal yang tidak sesuai } \\
\text { dengan fakta yang terjadi }\end{array}$ & $\mathbf{X}$ \\
\hline 2. & $\begin{array}{l}\text { b. Fitnah berarti tuduhan tanpa dasar yang dilakukan } \\
\text { secara sengaja dengan niat buruk }\end{array}$ & \\
\hline 3. & c. Sadis berarti kejam dan tidak mengenal belas kasihan & & \\
\hline 4. & $\begin{array}{l}\text { d. Cabul berarti penggambaran tingkah laku secara erotis } \\
\text { dengan foto, gambar, suara, grafis atau tulisan yang } \\
\text { semata-mata untuk membangkitkan nafsu birahi }\end{array}$ & $\begin{array}{l}\text { Y } \\
\text { e. Dalam penyiaran gambar dan suara arsip,wartawan } \\
\text { mencantumkan waktu pengambilan gambar dan suara }\end{array}$ & \\
\hline 5. & & $\mathbf{Y}$ \\
\hline
\end{tabular}

Keterangan : V peliputan; X penulisan ; Y editing

Kebohongan wartawan dapat dilakukan dalam beberapa cara misal melakukan wawancara fiktif, memberikan fakta yang sebenarnya tidak ada, memberitahukan sesuatu yang tidak sesuai dengan fakta yang diketahui, dan memalsukan data. Meskipun ada naskah namun hasil akhir informasi tersebut tergantung pada data informasi dan gambar yang diperoleh saat peliputan. Dari naskah awal atau naskah kasar menjadi naskah final berdasarkan apa yang diperoleh di lapangan. Berkaitan dalam menerapkan tidak membuat berita bohong, fitnah key informan Bagus Adi Nugroho, penulis naskah Sigi menjelaskan:

“...kalo memang lagi terpepet, harus buru-buru nulis naskah sedangkan gambar kita juga masih ada yang proses pengambilan selanjutnya. Ya itu.. biasanya saya mengira-ira saja. Seperti.. besok masih ada liputan, besok kemungkinan liputan ini, dapat gambar ini..Ya sudah saya tulis naskah kasar dulu. Setelah liputan dilapangan..Kalo memang sesuai dengan naskah kasar ya tidak ada perubahan tapi kalau hasilnya gini ya.. saya ubah naskah kasarnya....."(Wawancara dengan
Bagus Adi Nugroho, Penulis naskah dan Reporter Sigi, 25 Mei 2016)

Mengenai kebohongan Anggota dewan Pers Ratna Komala berpendapat,

"Indikasi bohong tidak memuat atau tidak mencantumkan apa yang sebenarnya. ia memang memiliki itikad buruk tidak mencantumkan yang sebenarnya misalnya dia tahu bahwa itu tidak ia lakukan tapi ia bilang dia lakukan. Kalau itu bohong jelas- jelas menuduh sesuatu yang ia tahu tidak benar. Memuat sesuatu yang tidak benar." (Wawancara dengan Ratna Komala, Anggota Dewan Pers pada 23 Agustus 2016)

Berkaitan pasal 4 penafsiran a pada penulisan naskah sigi terdapat kesesuaian. Pada Tayangan Sigi di hari Minggu, 4 Juni 2016. Episode Awas Predator Anak. Penulis menemukan adanya anak-anak yang sedang menyaksikan film porno di sebuah warnet. Gambar adegan cabul pada layar komputer diblur sekaligus pada sekolompok anak penikmat tayangan porno. Berkaitan dengan unsur cabul tersebut key informan Muhammad Yunus Firdaus, Editor Sigi menjelaskan:

"Saya pasti bilang itu..mau pake ini atau kita bluur."(Wawancara dengan 
Muhammad Yunus Firdaus,Editor Sigi 14 Mei 2016)

Hal yang sama dari key informan Didi Hidayat, Editor Sigi mengungkapkan,

"Erotis ya diblur.blur biasa. bukan mozaik blur yang halus yang masih layak tonton...layak tonton tapi nggak juga bikin imajinasi penonton kalo terlalu tipis kan bikin imajinasi penonton macem - macem kan." (Wawancara dengan Didi Hidayat, Editor Sigi 14 Mei 2016)

Mengenai unsur cabul, Ratna Komala mengatakan,

"Sudah jelas ya kita punya semacam standart-standart yang berlaku umum gitu kan yang terkait dengan seksual sesuatu yang melanggar inilah susila, kesopanan, kepatutan, yang terkait sama seksual itu jelas tidak boleh, contohnya gini misal kasus perkosaan."(Wawancara dengan Ratna Komala, Anggota Dewan Pers pada 23 Agustus 2016)

Dilihat dari sisi tanggungjawab sosial media adalah agen of socialisation (agen sosialisasi), sebagai agen informasi, kalau yang disiarkan adalah keburukankeburukan maka media menjadi agen keburukan karena itu media menjaga norma-norma dengan menekankan nilainilai kebaikan bukan seenaknya atas nama fakta media bisa bebas menampilkan. Disinilah ada tanggungjawab sosial media.

Berkaitan dengan Pasal 4 wartawan tidak membuat berita cabul dari data dan wawancara terdapat kesesuaian penerapan, yaitu Editor Sigi menyamarkan gambar yang mengandung unsur cabul.

Pada Tayangan Sigi di hari Minggu, 4 Juni 2016. Episode Awas Predator Anak. penulis mendapatkan satu visual dokumentasi tertanggal 19 Mei 2016 dari Kota Kediri, yakni suasana di ruang sidang pengadilan dengan terdakwa pelaku kejahatan seksual. Berkaitan dengan mencantumkan waktu pengambilan gambar key informan Muhammad Yunus Firdaus, Editor Sigi menjelaskan,

"O iya saya menuliskan courtesy atau dok. Biasanya reporter atau produser minta ambil dari library dan akan menuliskan 'dok'. Pas editor ngambil gambar sudah ada tulisan 'dok'. Biasanya di naskah juga ada tulisan 'dok'." (Wawancara dengan Muhammad Yunus Firdaus, Editor Sigi pada $14 \mathrm{Mei}$ 2016)

Hal yang tidak jauh berbeda disampaikan oleh key informan Didi Hidayat yang mengatakan:

“ Biasanya ada.. tanggalnya. Ya ketahuan biasanya di Nama filenya itu ada 'dok'. Dinaskahnya juga ada tulisan dok. Ini dok SCTV tanggal berapa. kita editor nanti nulis tanggalnya.."(Wawancara dengan Didi Hidayat, Editor Sigi pada 14 Mei 2016)

Berkaitan dengan Pasal 4 penafsiran butir e terdapat kesesuaian penerapan, yakni dicantumkannya tanggal pengambilan gambar untuk menjelaskan pada audiens bahwa gambar diambil dari arsip dilakukan tim Sigi.

Pada penerapan Pasal 5 di tahap Peliputan ditemukan sebanyak 1 (satu) 
kesesuaian. Kesesuaian Pasal 5 tersebut pada penafsiran poin a. Di tahap Penulisan naskah kami menemukan sebanyak 1 (satu) kesesuaian. Kesesuaian Pasal 5 tersebut pada penafsiran poin a. Penulis menemukan di tahap pascaproduksi sebanyak 1 (satu) kesesuaian. Kesesuaian Pasal 5 tersebut pada penafsiran point a.
Pasal 5:

Wartawan Indonesia tidak menyebutkan dan menyiarkan identitas korban kejahatan susila dan tidak menyebutkan identitas anak yang menjadi pelaku kejahatan. Di bawah ini tabel penerapannya (lihat tabel 4).

Tabel 4

Penerapan KEJ Pasal 5 pada Peliputan, Penulisan dan Editing Sigi

\begin{tabular}{|l|l|c|c|}
\hline NO. & \multicolumn{1}{|c|}{$\begin{array}{c}\text { POINT/BUTIR } \\
\text { PENAFSIRAN }\end{array}$} & \multicolumn{2}{|c|}{ HASIL PENELITIAN } \\
\cline { 3 - 4 } & $\begin{array}{l}\text { a. Identitas adalah semua data dan informasi yang } \\
\text { menyangkut diri sesorang yang memudahkan orang lain } \\
\text { untuk melacak }\end{array}$ & & PELANGGARAN \\
\hline 2. & $\begin{array}{l}\text { b. Anak adalah seorang yang berusia kurang dari 16 tahun } \\
\text { dan belum menikah }\end{array}$ & & \\
\hline
\end{tabular}

Keterangan : V peliputan; $\mathrm{X}$ penulisan ; Y editing

Dalam Tayangan Sigi Minggu, 06 Maret 2016 Episode Lika-Liku Bisnis Haram Aborsi, penulis mendapatkan visual wawancara dengan korban praktik aborsi. Dalam tayangan tersebut narasumber disembunyikan wajahnya dengan jalan diberi efek blur (Gambar $1)$.

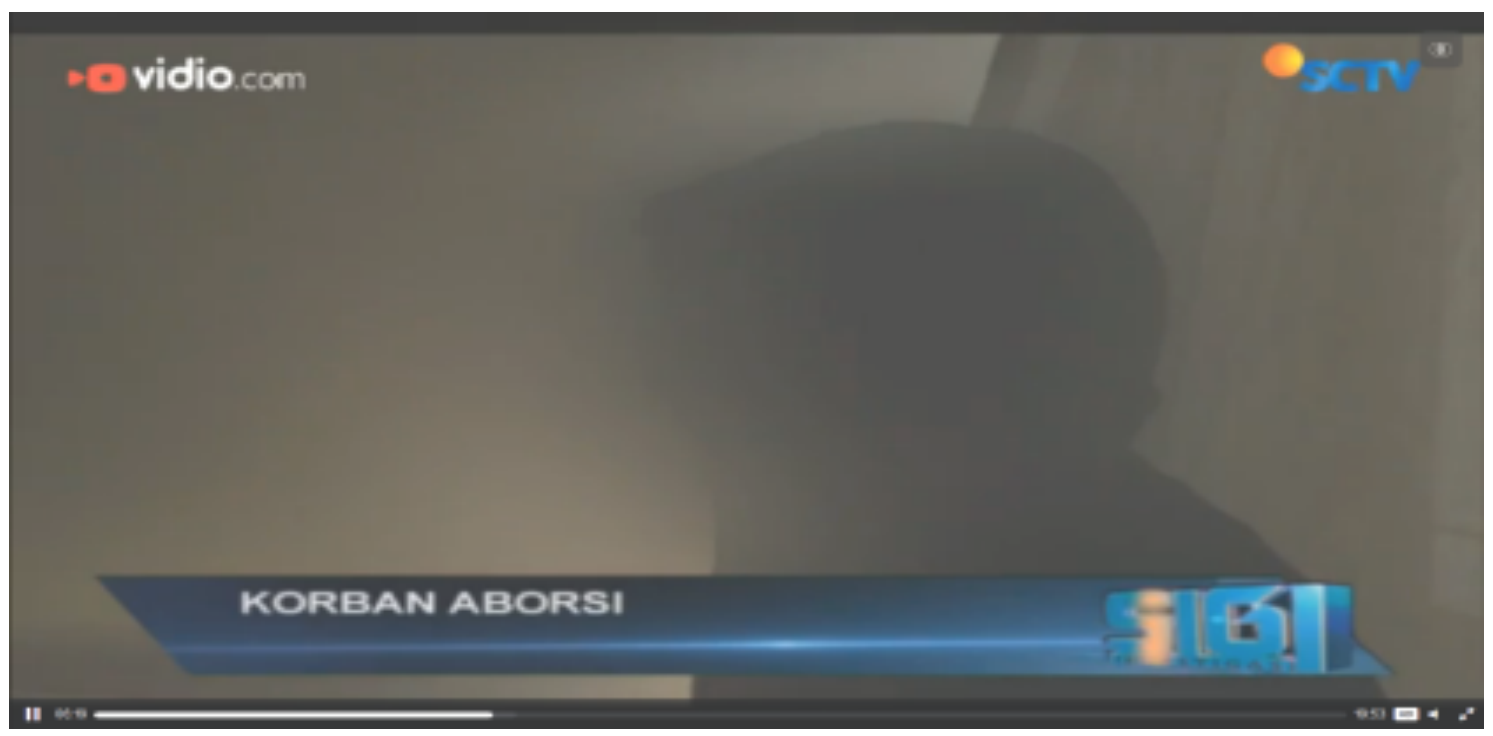

\section{Gambar 1 Visual Wawancara Korban Aborsi}

Berkaitan dengan tidak menyebutkan identitas perempuan korban kejahatan key informan Dwi Sapto, Reporter Sigi menjelaskan: 
"Kurang lebih salah satu cara diblur..kemudian kita bisa bukan mensiasati ya..tetapi mencoba memberikan teknik lain semisal semisal kalau dalam urusan kemarin kita sempet wawancara ya. ada pertanyaaanpertanyaan sekiranya sedikit mengganggulah... artinya tidak seharusnya ini dikeluarkan gitu, kita bisa mensiasati dengan bahasa lain semisal artinya di narasi kita siasati." (Wawancara dengan Dwi Sapto, Reporter Sigi, 03 Juni 2016)

Dalam episode Bayang-Bayang Predator Anak pada naskah narasi juga tidak tertulis nama si korban kekerasan seksual. Berikut petikan narasi dalam tayangan di hari Minggu, 28 Mei 2016:

SEKILAS /TIDAK ADA YANG GANJIL DENGAN REMAJA YANG BARU BERUSIA 15 TAHUN INI// NAMUN DIBALIK ITU ADA KISAH MENGENASKAN YANG MENIMPA DIRINYA//

Berkaitan tidak menyebutkan identitas anak yang menjadi pelaku kejahatan key informan Bagus Adi Nugroho, penulis naskah Sigi menjelaskan:

"Kalau di Sigi narasumber kan sebagai orang yang harus dilindungi. Apalagi dalam kasus kriminal dan segala macemnya. Prostitusi dan segala macam memang harus dilindungi. Hampir sama antara anak- anak dan subjek lainnya. Yang jelas kita memperlakukannya serahasia mungkin..."(Wawancara dengan Bagus Adi Nugroho, Penulis naskah dan Reporter Sigi, 25 Mei 2016)
Pada Tayangan Sigi di hari Minggu, 4 Juni 2016. Episode Awas Predator Anak. Penulis mendapatkan pelaku transaksi keperawan di blur sehingga wajahnya tidak dikenali publik namun dapat teridentifikasi jika pelaku masih anak Sekolah Menengah Atas. Berkaitan dengan tidak menyebutkan identitas anak yang menjadi pelaku kejahatan key informan Muhammad Yunus Firdaus menjelaskan

"Disini selain blur pelaku saksi juga perlu diblur suara dan lokasi.agar tidak membahayakan. Ini Menghindari konflik sama pelaku makanya kita samarkan suara samarkan wajah dan lokasinya." (Wawancara dengan Muhammad Yunus Firdaus, Editor Sigi pada 14 Mei 2016)

Hal yang sama juga ditegaskan Key informan Didi Hidayat, Editor video Sigi

“ Disini selain blur pelaku saksi juga perlu diblur suara dan lokasi agar tidak membahayakan. Ini Menghindari konflik sama pelaku makanya kita samarin suara samarkan wajah dan lokasinya." (Wawancara dengan Didi Hidayat, Editor Sigi pada 14 Mei 2016)

Mengenai menyembunyikan identitas Ratna Komala berpendapat,

"Bukan hanya identitas dia pribadi (nama alamat), adik, kakak, keluarga, lingkungan sekitarnya juga rumah sekitarnya juga tidak boleh. Kalau orang jelas diblur keluarga jelas diblur informasi- informasi itu tidak diperlukan juga kecuali peristiwanya ya..."(Wawancara dengan Ratna Komala, Anggota Dewan Pers pada 23 Agustus 2016) 
Dengan analisa Teori Tanggungjawab Sosial penulis berpendapat ketatnya moral yang dianut dalam Kode Etik Jurnalistik pada aturan melindungi identitas karena memiliki niat tetap menjaga masa depan korban susila maupun pelakunya yang masih anakanak. Menurut penulis meski masyarakat sekarang berpikir modern dan sosial kemasyarakatan makin terbuka tapi menyangkut hal kesusilaan masih merupakan hal yang peka. Sehingga redaksi Sigi melakukan blur pada visual maupun tidak menyebutkan nama pelaku dalam naskah untuk melindungi keselamatan dan masa depan korban kejahatan susila maupun pelaku yang notabene perempuan dan usia anak-anak. Masa depan mereka yang menjadi perhatian karena pemberitaan memiliki pengaruh besar dan dikhawatirkan akan memengaruhi perkembangan kejiwaan anak jika identitasnya dipublikasikan. Kepekaan dalam menyembunyikan pelaku merupakan kesadaran redaksional mengukur tingkat distorsi artinya ketika hendak mengangkat peristiwa para korban diperlukan hitungan bencana yang akan menimpa para korban. Ketika pemberitaan hendak menampilkan foto atau visual diperlukan upaya menghitung dampak penyebaran di masyarakat. Sebagai lembaga penyiaran televisi yang dapat memberi pengaruh kuat pada tatanan nilai, kehidupan dan penghidupan hendaknya jurnalis dilandasi moral yang tinggi.

Berkaitan dengan Pasal 5 dari hasil data dan wawancara pada tahapan liputan, penulisan naskah dan editing program Sigi terdapat kesesuaian penerapan, yaitu menyembunyikan korban kejahatan susila atau pelaku yang masih anak-anak.

\section{Independensi dalam Produksi JurnalismeTelevisi Investigasi Sigi}

\section{Ada tidaknya Opini}

Pada tayangan Sigi dihari Minggu, 20 Maret 2016. Prahara Transportasi Laut Indonesia penulis menemukan adanya beberapa fakta yang menjadi penyebab kecelakaan transportasi laut yang disajikan tim Sigi yakni tidak adanya lasting yang terpasang di kendaraan yang ada di atas kapal feri, tidak jelasnya penghitungan jumlah penumpang dalam kendaraan, adanya unsur praktik kecurangan di jembatan timbang. Berkaitan dengan ada tidaknya opini yang mempengaruhi independensi key informan Dwi Sapto, Reporter Sigi mengatakan:

"Gini mengkira-kira tidak boleh, sudah pasti tidak boleh. Ketika data kita tidak kuat, kita jangan main disitu. kita hindari sebisa mungkin dihindari. Semisal tenggat waktu minim ya apa yang kita dapat dilapangan kita kerjakan, jika tidak terlalu kuat kalau saya pribadi saya tidak main disitu, saya tidak akan berani. Saya coba mengikuti apa yang saya dapat dilapangan." (Wawancara dengan Dwi Sapto,Reporter Sigi, 03 Juni 2016)

Pers harus menampilkan fakta apa adanya, tidak boleh kurang dan lebih. Berkaitan dengan opini key informan Bagus Adi Nugroho menjelaskan:

..kalau saya kan sekaligus reporter ya. Ya memang saya harus konfirmasi langsung. Jadi saya dengar cerita langsung dari narasumber Jadi bukan dari orang lain ya. Ya narasumber ya 
saya yang tanya. (Wawancara dengan Bagus Adi Nugroho, Penulis naskah dan Reporter Sigi, 25 Mei 2016)

Berdasarkan teori pers Tanggungjawab Sosial, Pers harus menampilkan fakta apa adanya, tidak boleh kurang dan lebih, tidak mengandung unsur dugaan sehingga apa yang disampaikan benar dari apa yang disuarakan narasumber, yang dilihat dilapangan, yang sesuai dengan data, dokumen. Ada 3 kewajiban pers yang harus diperhatikan:

1. Menjunjung tinggi kebenaran

2. Wajib menghormati privacy orang atau subyek tertentu

3. Wajib menjunjung tinggi prinsip bahwa apa yang diwartakan atau diberitakan dapat dipertanggungjawabkan

Unsur opini akan mempengaruhi netralitas dan independensi karena melihat sesuatuberdasarkan sudut pandang reporter/jurnalisnya yang kadang dipengaruhi orientasi individu dan nilai nilai kepentingan yang dianut wartawan tersebut, apabila di sebarkan ke masyarakat akan berbahaya karena jauh dari tujuan informasi yang Fair.

Dari hasil data dan wawancara tidak ditemukan adanya opini, tim Sigi menyajikan beberapa bukti yang ditemukan di lapangan untuk melengkapi dan memperkuat data dan informasi.

\section{Sensasionalisme}

Dalam tayangan Sigi Bayang Bayang Predator Anak Minggu, 4 Juni 2016 penulis mendapatkan wawancara seorang ibu yang menangis karena menjual keperawanan anak gadisnya buat berobat suaminya yang sedang sakit. Sehingga ada sensasi dramatisnya (Gambar 2)

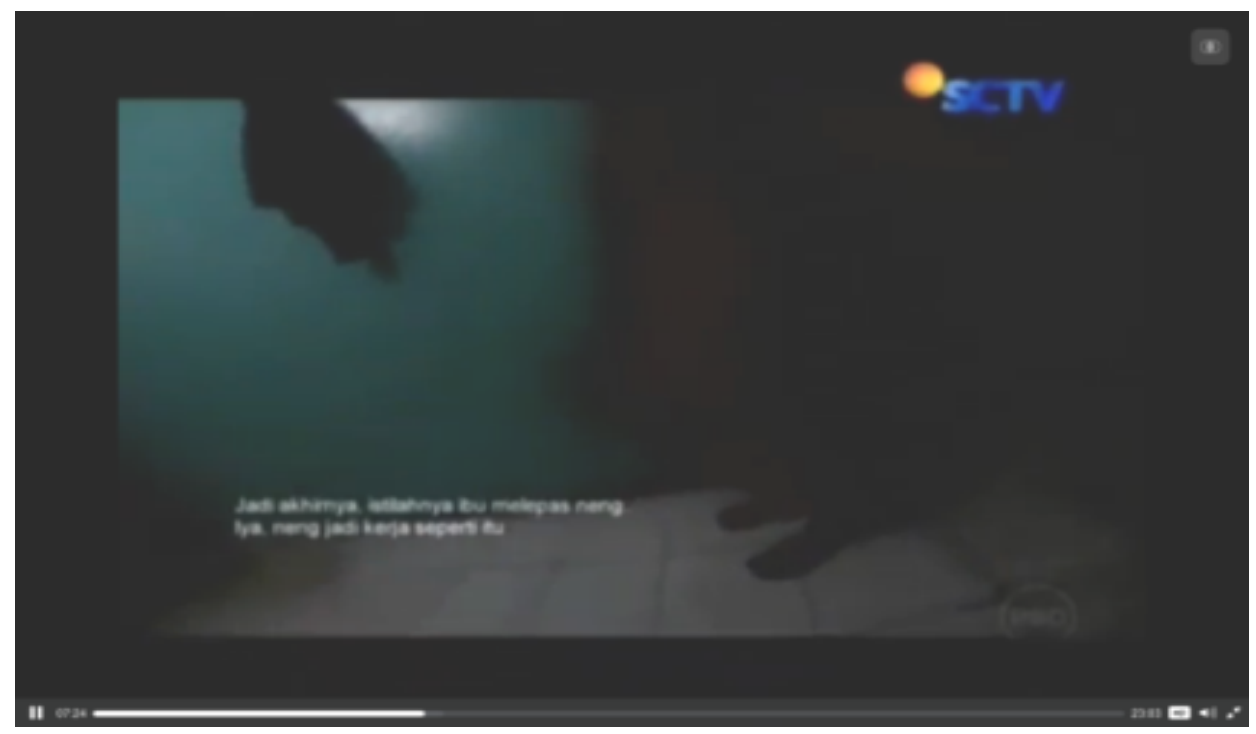

Gambar.2 Visual Wawancara dengan Ibu dari Pelaku Seks Anak 
Berkaitan dengan sensasionalisme key informan Ari Trisna, Video Jurnalis Sigi menjelaskan:

"Biasanya sih kita untuk pemilihan gambar biasanya yang nangis itu kita utamakan seperti yang nangis seperti mereka emosi marah itu memang itu sama aja untuk mancing mas mancing pemirsa wiiih ada apa sih? Kalau kita awalnya kita datar nanti orang pindah chanNel mas pokoknya awalnya kita jebret langsung tinggi biarpun disegment dua mo turun segment 3 kita naikkan lagi.untuk pemilihan gambar kita." (Wawancara dengan Ari Trisna, video jurnalis Sigi pada 20 Juni 2016)

Mengenai hal sensasionalisme key informan Ratna Komala, Dewan Pers mengatakan,

"Kalau pemirsanya merasa trenyuh karena beritanya ya itu situasi alamiah tapi gini lho jadikan itu komoditas.. jangan jadikan kesedihan orang itu komoditas.. jadi itu diekspolitasi habishabisan gak boleh juga. ..masak lagi sedih kita eksploitasi." (Wawancara dengan Ratna Komala, Anggota Dewan Pers pada 23 Agustus 2016)

Pada Tayangan Sigi Minggu 03 April 2016 di episode Bencana Tanah Longsor di Batulawang, pada awal tayangan penulis mendapatkan unsur visual maupun audio berdurasi pendek. Yakni cuplikan proses evakuasi diiringi suara doa-doamenambah makin meningkatnya suasana getir bencana. Berkaitan dengan unsur gambar dramatis di video teaser key informan Bagus Adi Nugroho, penulis naskah Sigi menjelaskan

"Iya pasti. jadi kalo diawalkan biasanya kita di Sigi gambar diawal itu gambar yang menarik. Biar orang itu pertamakali menonton tidak istilahnya memindah channel...Ya itu balik lagi ke gambargambar cantik saja gambar dramatis terutama. Misal emosi penonton ingin dibikin kayak apa sih..? misalnya sedih. mainin cerita cerita sedih.. ataupun gambar-gambar sedih. Kalo misal butuh emosi yang meledak-ledak cari gambargambar demo misalnya."(Wawancara dengan Bagus Adi Nugroho, Penulis naskah dan Reporter Sigi, 25 Mei 2016)

Pada Tayangan Sigi Bayang - Bayang Predator Anak tanggal 28 Mei 2016 penulis mendapatkan video teaser atau video pembuka yang cukup dramatis dari sisi visual yakni gambar gambar anak, demo dan dari sisi Audio menonjolkan Sound bite " KEKERASAN ANAK DAMPAKNYA LUAR BIASA" yang didukung ilustrasi musik. Berkaitan dengan penambahan efek dramatis ini dalam tayangan Sigi key informan Muhammad Yunus Firdaus berpendapat,

"Gambar di slomotion dikasih effect zoom in, perubahan warna coloring dan audio sound effect. Kadang Selera produser kadang selera reporter." (Wawancara dengan Muhammad Yunus Firdaus,Editor Sigi 14 Mei 2016)

Pendapat sedikit berbeda disampaikan key Informan Didi Hidayat, Editor Sigi

"Dramatisasi tapi masih yang wajar. Memang liputan Sigi ini kadang menegangkan kadang sembunyi sembunyi mengemasnya sesuai dengan situasi yang terjadi dilapangan. Kalau misalnya menegangkan ya dikasih musik tegang. atau ada hal yang perlu diperjelas..diperjelas. misalnya mendapatkan gambar di still di zoom biar penonton tidak melewatkan informasinya. Atau di slomotion 
"(Wawancara dengan Didi Hidayat, Editor Sigi 14 Mei 2016)

Mengenai video teaser yang menampilkan unsur memainkan emosi penonton informan Ratna Komala menjelaskan,

"Kalau teaser itu kan sebetulnya mengajak orang untuk e nonton nonton gitu kan tapi belum ke beritanya baru teaser...bagaimana membuat berita yang akan ditayangkan itu menjadi lebih menarik ke pemirsanya intinya hal yang pentingnya tapi jangan mengekspoitasi ya itu tadi seksual kebohongannya. Sepanjang tidak melanggar etika teaser itu strategi sebenarnya. Teaser membuat penonton tertarik menonton." (Wawancara dengan Ratna Komala,
Anggota Dewan Pers pada 23 Agustus 2016)

Berkaitan dengan sensasionalisme dari hasil observasi data dan wawancara, pada Sigi Investigasi ditemukan adanya unsur sensasionalisme.

\section{Juxtaposition}

Pada Tayangan Sigi Minggu 03 April 2016 di episode Bencana Tanah Longsor di Batulawang, penulis mendapatkan ada 2 peristiwa longsor yang berbeda tempat, yakni di Banjarnegara, Jawa Tengah dan di Cipanas, Jawa Barat dipersandingkan. Kedua peristiwa itu menambah semakin besar nilai berita longsor pada peristiwa utama yakni longsornya hotel Bali Club.
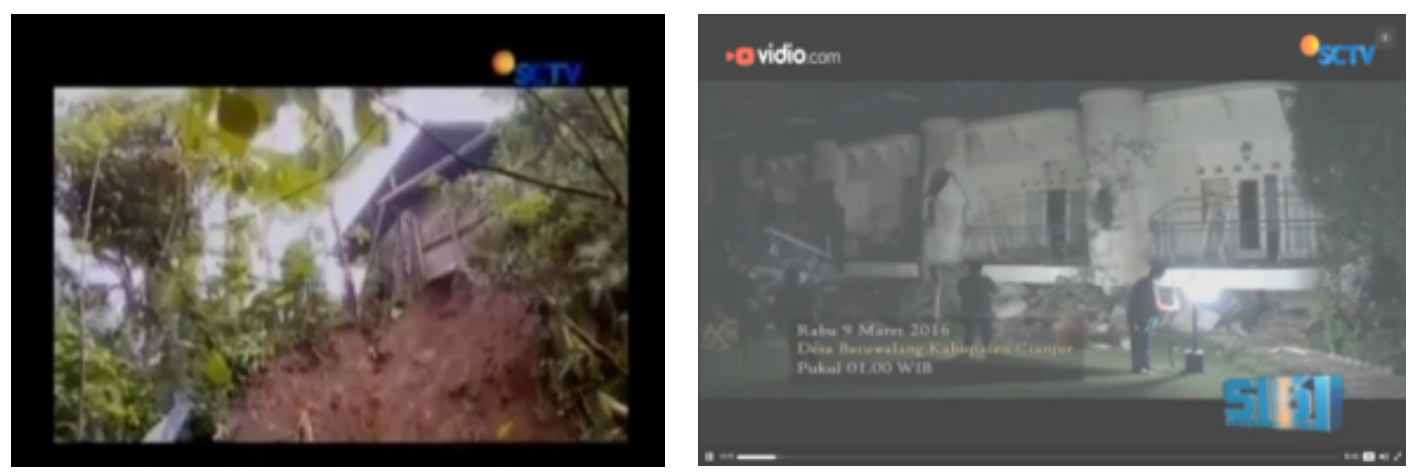

\section{Gambar 3 Juxtaposition dalam Sigi}

Tujuan disandingkannya dua peristiwa dalam satu tayangan Sigi dijelaskan key informan Ari Trisna, Video Jurnalis Sigi berikut ini

"O Dengan waktu yang berbeda tapi beritanya sama ya mas ya $\mathrm{Na}$ Itu sih sebenarnya kita hanya mengingatkan berita, kejadian ini sebelumnya itu ada juga kejadian serupa tapi kok pemerintah kayak tidak tanggap itu mas kita hanya untuk flasbacknya aja....tahun kemarin udah ada longsor kok ada longsor lagi.

Yang kedua memang untuk durasi juga sih." (Wawancara dengan Ari Trisna, video jurnalis Sigi pada 20 Juni 2016)

Mengenai menyandingkan 2 peristiwa dalam satu topik bahasan informan Ratna Komala menjelaskan,

"Boleh saja kita punya peristiwaperistiwa misal gempa dahsyat Me rep up kejadian sebelumnya sebagai referensi itu boleh boleh saja setelah sekian tahun.itu boleh boleh saja." 
(Wawancara dengan Ratna Komala, Anggota Dewan Pers pada 23 Agustus 2016)

Berdasarkan dari hasil observasi data dan wawancara di temukan ada unsur juxtaposition, yakni mempersandingkan dua peristiwa dalam penulisan naskah Sigi yang dilakukan untuk menambah perhatian audiens dengan tema yang diangkat yakni longsor Pada episode Bencana Tanah Lonsor di Batu Lawang.

\section{Akurasi}

Pada Tayangan Sigi di hari Minggu, 4 Juni 2016. Episode Awas Predator Anak. Penulis menemukan adanya beberapa narasumber yang berkompeten dengan topik eksploitasi seks pada anak mulai dari KPAI, Kepolisian, Kriminolog, LSM. Berkaitan dengan akurasi dalam peliputan key informan Dwi Sapto, Reporter Sigi menjelaskan

pokoknya intinya gini .. data yang kita dapat jangan main main jika data itu tidak kuat, jangan pernah mengasumsi, menduga. apa yang ada ya kita garap. (Wawancara dengan Dwi Sapto,Reporter Sigi, 03 Juni 2016)

Menjelaskan mengenai akurasi key informan Ratna Komala menyampaikan,

"Tidak akurat kalau misanya nya ya tadi datanya tidak dikonfirmasi kepada narasumbernya. Tidak di konfirmasi langsung ke lapangan sebagai sumber informasi nomer satu first hand information, sumber informasi pertama, jadi dia bukan baca dari buku, bukan baca dari Koran bukan baca dari apapun tapi langsung kelapangan itu memverifikasi." (Wawancara dengan Ratna Komala, Anggota Dewan Pers pada 23 Agustus 2016)

Analisa dari teori Tanggungjawab Sosial, akurasi merupakan indikator perihal ketelitian dan kecermatan. Akurasi merupakan refleksi rasa tanggungjawab wartawan dan media massa yang bersangkutan. Akibat ketidak akuratan itu terkadang merugikan sumber berita atau pihak pihak lain. Bukan hanya sekedar protes dan marah pihak lain tersebut juga bisa mempidanakan atau menggugatnya melalui jalur hukum demikian resiko kalau tidak akurat dalam pemberitaaan. Akurasi menjadi jaminan bagi reputasi kewartawanannya dan medianya. Supaya akurat dilakukan check dan recheck. Untuk memenuhi janji bahwa jurnalisme mencari dan menyampaikan kebenaran maka pertama-tama, informasi yang hendak disampaikan ke masyarakat lebih dulu ditapis dengan takaran keakuratan.

\section{SIMPULAN}

Berdasarkan pembahasan data dan analisis diatas dapat disimpulkan bahwa didapatkan Kesesuaian dan Pelanggaran Kode Etik Jurnalistik.

Pada peliputan program investigasi Sigi SCTV dari pasal 2 KEJ kesesuaian meliputi; menunjukkan identitas diri kepada narasumber (poin a), menghormati hak privasi (poin b), menghasilkan berita yang faktual dan jelas sumbernya (poin d), tidak melakukan plagiat termasuk menyatakan 
hasil liputan wartawan lain sebagai karya sendiri (poin g), penggunaan cara-cara tertentu dapat dipertimbangkan untuk peliputan berita investigasi bagi kepentingan publik (poin h). Sedangkan dalam pasal 2 diketemukan ada ketidaksesuaian atau pelanggaran pada penafsiran poin c tidak menyuap, karena dalam praktek peliputan ada indikasi pemberian imbalan terhadap narasumber. Pada Penerapan Pasal 3 terdapat kesesuaian dengan penafsiran pada poin a, menguji informasi berarti melakukan check dan richeck tentang kebenaran informasi dan poin $b$, berimbang adalah memberikan ruang dan waktu pemberitaan kepada masingmasing pihak secara proporsional. Pada pasal 5 juga terdapat kesesuaian penerapan pada penafsiran point a, yaitu Identitas adalah semua data dan informasi yang menyangkut diri sesorang yang memudahkan orang lain untuk melacak.

Penerapan Kode Etik jurnalistik pada penulisan naskah program investigasi Sigi SCTV terdapat kesesuaian pada pasal 3, pasal 4, dan pasal 5. Kesesuaian ini meliputi pada penafsiran menguji informasi berarti melakukan check dan richek tentang kebenaran informasi (pasal 3 poin a), Bohong berarti sesuatu yang sudah diketahui sebelumnya oleh wartawan sebagai hal yang tidak sesuai dengan fakta yang terjadi (pasal 4 poin a), Identitas adalah semua data dan informasi yang menyangkut diri sesorang yang memudahkan orang lain untuk melacak (pasal 5 poin a).

Penerapan Kode Etik jurnalistik pada editing program investigasi Sigi SCTV terdapat kesesuaian dengan pasal 4 dan pasal 5. Pada pasal 4 kesesuaian tercermin pada penafsiran poin $\mathrm{d}$ cabul berarti penggambaran tingkah laku secara erotis dengan foto, gambar, suara, grafis atau tulisan yang semata-mata untuk membangkitkan nafsu birahi dan poin e dalam Penyiaran gambar dan suara dari arsip, wartawan mencantumkan waktu pengambilan gambar dan suara.

Independensi dalam program investigasi Sigi SCTV dilihat dari indikator Opini. Peliputan program tersebut belum ditemukan unsur opini dikarenakan Sigi lebih mengedepankan bukti-bukti dilapangan, informasi akan dikemukakan apabila ditemukan bukti yang kuat. Sedangkan pada penulisan naskah unsur opini juga tidak diketemukan karena penulis naskah juga melakukan peliputan sehingga apa yang disusun dalam naskah berasal dari gambar dan data yang penulis naskah ketahui langsung dari narasumber yang ia temui.

Independensi dari indikator sensasionalisme peliputan Sigi SCTV dan pascaproduksi unsur sensasionalisme memang ada dikarenakan hal-hal tersebut menarik minat dari masyarakat namun belum melanggar etika.

Independensi dalam program investigasi Sigi SCTV dilihat dari 
indikator Juxtaposition, penulisan naskah Sigi ada unsur juxtaposition, meski tidak melanggar etika hal ini bertentangan dengan prinsip independensi.

Independensi dalam program investigasi Sigi SCTV dilihat dari indikator Akurasi. Peliputan Sigi SCTV terdapat unsur akurasi, yaitu digunakannya beberapa narasumber yang berkompeten sehingga nilai akurasi berita tinggi. Sedangkan penulisan naskah Sigi memilih penggunaan bahasa baku dan jelas sehingga mampu merangkai gambar ke gambar dengan akurat.

\section{UCAPAN TERIMAKASIH}

Peneliti mengucapkan terimakasih kepada Allah SWT yang telah memberikan kesehatan dan kesempatan melakukan penelitian ini, seluruh rekan Dosen dan Civitas Akademi di Universitas Budi Luhur, terimakasih Kepada para narasumber dari tim produksi Sigi, terimakasih Ibu Ratna Komala dari Dewan Pers.

\section{DAFTAR PUSTAKA}

Armada, Wina Sukardi. (2008). Cara Mudah Memahami Kode Etik Jurnalistik \& Dewan Pers. Jakarta: Dewan Pers.

Badjuri, Adi. (2010). Jurnalistik Televisi. Yogyakarta: Graha Ilmu.
Baran, Stanley J \&Dennis K Davis. (2010). Teori Komunikasi Massa, edisi 5 Dasar, Pergolakan dan Masa Depan. Jakarta: Salemba Humanika.

Departemen Pendidikan Nasional. (2007). Kamus Besar Bahasa Indonesia Edisi ketiga. Jakarta: Balai Pustaka.

Fachruddin, Andi. (2012). Dasar-Dasar Produksi Televisi: Produksi Berita, Feature, Laporan investigasi, Dokumenter, dan Teknik Editing. Jakarta: Kencana Prenada Media Group.

Kriyantono, R. (2006). Teknis Praktis Riset Komunikasi:Disertai Contoh Praktis Media,Publik Relation, Advertising, Komunikasi Organisasi, Komunikasi Pemasaran. Jakarta: Kencana Prenada Media Group.

McQuail, Dennis. (2011). Teori Komunikasi Massa McQuail. Jakarta: Salemba Humanika.

McQuail, Dennis. (1992). Media Performance: Mass Communication and The Public Interest. New Delhi: Sage Publications.

Santana, Septiawan. (2009). Jurnalisme Investigatif. Jakarta: Yayasan Obor Indonesia. 
Seno, Indriyanto Adji. (2008). Hukum dan Kebebasan Pers. Jakarta: Diadit Media.

Wibowo, Fred. (2007). Teknik Produksi Program Televisi .Yogyakarta: Pinus Book Publisher

Zaennuddin,HM (2011). The
Journalist, Bacaan Wajib
Wartawan, Redaktur, Editor \&
Para Mahasiswa Jurnalistik.
Bandung: Simbiosa Rekatama
Med

